\title{
EVALUASI SISTEM INSTALASI LISTRIK PADA MENARA TRANSMISI TELEKOMUNIKASI DI SITE UPDO07 TELKOMAS KOTA MAKASSAR
}

\author{
Udin Sidik Sidin ${ }^{1}$, Ryan Herianto ${ }^{2}$ \\ ${ }^{1}$ Pendidikan Teknik Elektro, Universitas Negeri Makassar \\ Udin.sidik.sidin@unm.ac.id \\ ${ }^{2}$ Pendidikan Teknik Elektro, Universitas Negeri Makassar \\ Ryanerianto1999@gmail.com
}

\begin{abstract}
ABSTRAK
Penelitian ini adalah penelitian kuantitatif dengan menggunakan metode survey yang bertujuan untuk mengetahui tingkat kelayakan instalasi listrik pada menara trasmisi telekomunikasi. Penelitian ini dilakukan pada site UPD007 Telkomas, Btp, Kota Makassar, Provinsi Sulawesi Selatan. Variabel pada penelitian ini adalah pengaman instalasi listrik, penghantar instalasi listrik, dan pembumian instalasi listrik. Teknik pengumpulan data yang digunakan adalah teknik observasi, dokumentasi, wawancara dan pengukuran. Teknik analisis data yang digunakan adalah analisis data deskriptif dengan menggunakan Persyaratan Umum Instalasi Listrik (PUIL) 2011. Hasil penelitian menunjukkan bahwa penggunaan pengaman instalasi listrik disetiap titiknya dikatakan layak berdasarkan jenis dan kapasitasnya. Penghantar instalasi listrik yang digunakan seluruhnya dikatakan layak berdasarkan luas penampang, sedangkan berdasarkan warna penghantar menunjukkan hanya seluruh penghantar netral, pembumian dan penghantar DC yang sesuai dengan standar menggunakan Persyaratan Umum Instalasi Listrik (PUIL) 2011. Resistansi Pembumian yang diperoleh pada setiap proteksi sepenuhnya dikatakan layak berdasarkan ketentuan Persyaratan Umum Instalasi Listrik (PUIL) 2011.
\end{abstract}

Kata Kunci: Evaluasi, Instalasi Listrik, Transmisi Telekomunikasi

\section{EVALUATION OF ELECTRICAL INSTALLATION SYSTEM ON TELECOMMUNICATIONS TRANSMISSION TOWER AT UPDOO7 TELKOMAS SITE, MAKASSAR CITY}

\begin{abstract}
This research is a quantitative research using survey method which aims to determine the feasibility level of electrical installations in telecommunications transmission towers. This research was conducted at the UPD007 Telkomas site, Btp, Makassar City, South Sulawesi Province. The variables in this study are electrical installation safety, electrical installation conductors, and electrical installation grounding. Data collection techniques used are observation, documentation, interview and measurement techniques. The data analysis technique used is descriptive data analysis using General Electrical Installation Requirements (PUIL) 2011. The results show that the use of electrical installation safety at each point is said to be feasible based on the type and capacity. All electrical installation conductors used are said to be feasible based on the cross-sectional area, while based on the color of the conductors it shows that only all neutral conductors, earth and DC conductors are in accordance with the standard using the General Electrical Installation Requirements (PUIL) 2011. The Earthing resistance obtained for each protection is fully said to be feasible. based on the provisions of the General Requirements for Electrical Installation (PUIL) 2011.
\end{abstract}

Keyword: Evaluation, Electrical Installation, Telecommunication Transmission 


\section{PENDAHULUAN}

Perkembangan kehidupan manusia tak lepas dari yang namanya teknologi dengan energi listrik sebagai penopangnya. Listrik digunakan diberbagai sektor kehidupan dalam rangka menunjang aktifitas kehidupan. Namun dalam penggunaan energi listrik, perlu memperhatikan perawatan dan pembaharuan pada instalasi listriknya, yang dapat menyebabkan resiko berbahaya bagi pemakainya. Dalam instalasi listrik terdapat beberapa hal yang perlu diperhatikan diantaranya material instalasi atau bahan, pemasangan instalasi, maupun standarisasi peraturan yang menyangkut tentang instalasi.

Pentingnya penggunaan energi listrik didalam kehidupan manusia dikarenkan semua peralatan yang menunjang kehidupan manusia menggunakan energi listrik. Dengan tersedianya listrik maka terjadi kemajuan peradaban dalam kehidupan manusia khususnya dalam bidang teknologi. Untuk keperluan penyediaan dan penyaluran energi listrik ke pelanggan, diperlukan berbagai peralatan listrik yang saling terhubung antara satu dengan yang lain sehingga mempunyai interelasi dan secara keseluruhan membentuk suatu sistem tenaga listrik. Dengan demikian sistem tenaga listrik merupakan kumpulan berbagai peralatan listrik yang terdiri dari pembangkitan, penyaluran, dan distribusi dimana antara satu dengan yang lain bekerjasama sehingga menghasilkan tenaga listrik, yang selanjutnya digunakan oleh pelanggan.

Semua orang menggunakan energi listrik dalam kehidupan sehari-hari, baik itu untuk penerangan, alat rumah tangga listrik, dan lain sebagainya. Listrik dapat menghubungkan orang satu dengan yang lainnya melalui jalur komunikasi audio maupun visual sehingga memudahkan penyebaran informasi sampai ke daerah pelosok yang belum dapat dijangkau dengan transportasi. Selain itu listrik juga sangat berguna dalam perkembangan ilmu pengetahuan dan teknologi dan menjadi tolak ukur kemajuan suatu negara. Pabrik-pabrik serta berbagai macam perindustrian sudah sangat bergantung pada ketersediaan energi listrik.

Pada bidang teknologi yang merupakan bagian terpenting dalam kehidupan masyarakat luas, perkembangan teknologi seluler terus mengalami perkembangan dari satu generasi ke generasi berikutnya. Dorongan bagi berkembangnya komunikasi bergerak terkait dengan faktor-faktor seperti adanya tuntutan dari segi kemudahan berkomunikasi dan kapasitas sistem, teknologi yang lebih murah, ukuran fisik sistem dan piranti yang lebih kecil dengan peningkatan kemampuan komunikasi sedapat mungkin mendekati kemampuan komunikasi yang menggunakan transmisi kabel, yang berdimensi multimedia (suara, data, grafik, dan gambar) [1].

Teknologi Microwave sebagai salah satu sistem komunikasi merupakan jaringan wireless yang memanfaatkan frekuensi tinggi yang biasanya dipergunakan untuk menghubungkan kedua base station seluler (BTS) [2]. Oleh karena itu, perencanaan jaringan link Microwave merupakan hal terpenitng untuk implementasi jaringan seluler terutama di kota-kota besar. Makassar sebagai salah satu kota terbesar di Indonesia tentu menginginkan keandalan sistem demi terpenuhinya kebutuhan akan jaringan seluler. Dalam pentransmisian sinyal, terdapat banyak faktor yang mempengaruhinya, yaitu redaman ruang bebas, refleksi, refraksi, atmosfer, fading, dan juga pantulan yang disebabkan oleh penghalang [3]. Selain itu, juga terdapat aspek penting dalam menunjang operasinya yaitu instalasi kelistrikan pada sistem Microwave itu sendiri. Maka untuk menjaga kelangsungan operasi di sistem ini, maka perlu diperhatikan keandalan dan keamanan pada sistem instalasi kelistrikannya.

Dalam penelitian ini akan dilakukan perencanaan link mircrowave pada menara menara transmisi tepatnya di Site UPD007 Telkomas, Btp, Kota Makassar, Provinsi Sulawesi Selatan. Instalasi kelistrikan pada sistem Microwave ini terletak pada suatu unit site sebagai tempat dilangsungkannya seluruh penginstalan dari perangkat Microwave. Site merupakan titik layanan milik provider yang didalamnya terdapat beberapa perangkat telekomunikasi seperti shelter, electrical, genset dan rumah genset, dan BTS (Base Transceiver Station) [4]. Dengan demikian untuk menjaga sistem operasi terkhusus pada perangkat transmisi pada site terlebih seringnya terjadi gangguan komunikasi seluler akibat padamnya radio Microwave, dibutuhkan persediaan energri listrik yang baik dan handal serta memenuhi faktor keamanan pada peralatan maupun manusia yang bekerja disekitarnya. Suatu sistem dikatakan handal apabila memiliki kabel penghantar, pengaman, serta resistansi pembumian yang baik sesuai dengan standar Persyaratan Umum Instalasi Listrik (PUIL) 2011 [5].

PT. Mitrasel Inti utama merupakan salah satu perusahaan yang bergerak dibidang telekomunikasi di Indonesia timur. Perusahaan ini awalnya bergerak pada pengerjaan perangkat transmisi dikembangkan ke pekerjaan sipil site dan BTS (Base Tranceiver Station). Namun saat ini hanya berfokus pada pengerjaan transmisi antena Microwave. Projectnya pun tersebar keseluruh kawasan Indonesia baik 
Sumatera, Kalimantan, Jawa, dan Sulawesi. Mengingat pengerjaan instalasi antena Microwave yang disediakan tersebar sangat banyak, namun perusahaan hanya intens mengerjakan instalasi Microwave ini di area Sulawesi Selatan. Berdasarkan data yang diperoleh dari salah satu karyawaan PT. Mitrasel Inti Utama menyatakan bahwa masih sering terjadi gangguan seperti hilangnya jaringan seluler akibat adanya masalah yang terjadi pada sistem Microwave ini. Maka peneliti menganggap perlu melakukan evaluasi terhadap sistem instalasi listrik sebagai bagian pertama dalam menemukan masalah pada satu unit site. Dengan demikian, hal tersebut memiliki peran yang baik agar apabila terjadi gangguan dapat diatasi dengan prosedur yang sama serta mengurangi resiko kerusakan yang parah.

\section{METODE PENELITIAN}

\section{Jenis Penelitian}

Jenis penelitian ini merupakan penelitian kuantitatif dengan menggunakan metode survey. Metode survey dilakukan dikarenakan data yang akan didapatkan berasal dari tempat tertentu yang alamiah (bukan buatan) [6].

\section{Desain Penelitian}

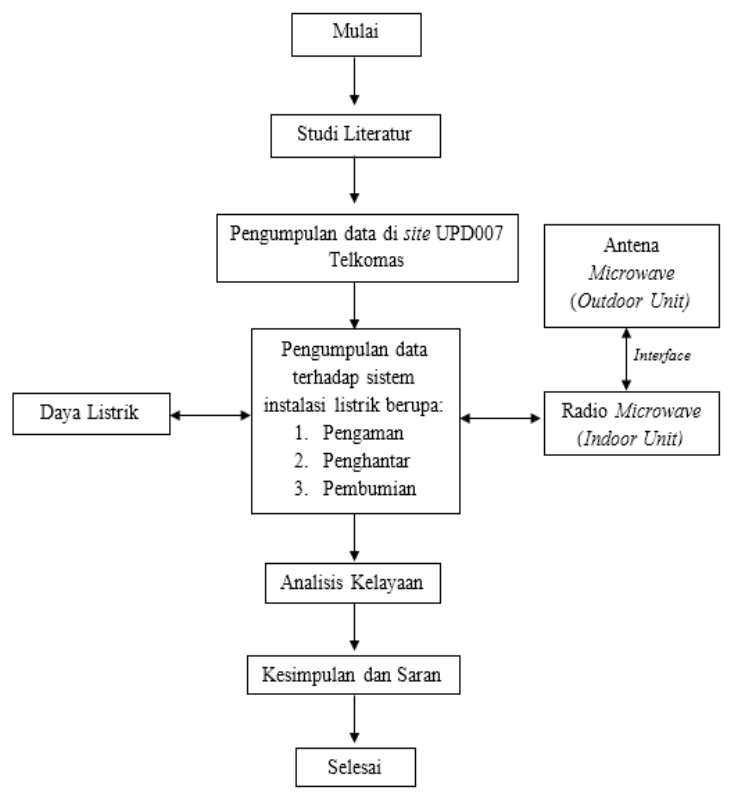

Gambar 1. Desain Penelitian

\section{HASIL DAN PEMBAHASAN}

\section{A. Jenis dan Kapasitas Pengaman}

Berdasarkan data penelitian, berikut ini merupakan tabulasi data penelitian yang berkaitan dengan pengaman instalasi yang digunakan pada menara transmisi telekomunikasi di site Telkomas UPD007.
TABEL 1. OBSERVASI ARUS PENGENAL PENGAMAN

\begin{tabular}{|c|c|c|c|c|}
\hline No & $\begin{array}{l}\text { Letak } \\
\text { Pengaman }\end{array}$ & $\begin{array}{l}\text { Jenis } \\
\text { Pengaman }\end{array}$ & $\begin{array}{l}\text { Merk } \\
\text { Pengaman }\end{array}$ & $\begin{array}{l}\text { Kapasitas } \\
\text { Pengaman } \\
\text { (Ampere) }\end{array}$ \\
\hline 1. & $\begin{array}{l}\text { Panel Listrik } \\
3 \text { phase }\end{array}$ & $\mathrm{MCCB}$ & Schneider & $100 \mathrm{~A}$ \\
\hline \multirow[t]{2}{*}{2.} & $\begin{array}{l}\text { ACPDB } \\
\text { (Alternate }\end{array}$ & $\begin{array}{l}\text { MCB } 3 \\
\text { Pahse x } 1\end{array}$ & Schneider & $25 \mathrm{~A} \times 1$ \\
\hline & $\begin{array}{l}\text { Current } \\
\text { Power } \\
\text { Distribution } \\
\text { Box) }\end{array}$ & $\begin{array}{l}\text { MCB } 3 \\
\text { Pahse x } 1\end{array}$ & $\begin{array}{l}\text { Merlin } \\
\text { Gerin / } \\
\text { Schneider }\end{array}$ & $63 \mathrm{~A} \times 3$ \\
\hline 3. & Input Rectifier & $\begin{array}{l}\text { MCB } 1 \\
\text { Pahse x } 3\end{array}$ & $\begin{array}{l}\text { Merlin } \\
\text { Gerin / } \\
\text { Schneider }\end{array}$ & $50 \mathrm{~A} \times 3$ \\
\hline 4. & $\begin{array}{l}\text { Output } \\
\text { Rectifier (DC } \\
\text { Distribution) }\end{array}$ & $\begin{array}{l}\text { MCB } 1 \\
\text { Phase }\end{array}$ & $\begin{array}{l}\text { Merlin } \\
\text { Gerin / } \\
\text { Schneider }\end{array}$ & $32 \mathrm{~A}$ \\
\hline
\end{tabular}

\section{B. Jenis dan Spesifikasi Penghantar}

1. Luas Penampang

Untuk menentukan kelayakan penampang penghantar atau ukuran minimum yan harus digunakan, dilakukan observasi dan pengukuran berkaitan dengan tujuan penelitian.

TABEL 2. HASIL OBSERVASI DAN PENGUKURAN ARUS PENAMPANG

\begin{tabular}{llcll}
\hline No & $\begin{array}{l}\text { Letak } \\
\text { Penghantar }\end{array}$ & $\begin{array}{l}\text { Status } \\
\text { Penghantar }\end{array}$ & $\begin{array}{l}\text { Jenis dan } \\
\text { Luas } \\
\text { Penampang } \\
\text { (mm }^{2} \text { ) }\end{array}$ & $\begin{array}{l}\text { Hasil } \\
\text { ukur } \\
\text { (A) }\end{array}$ \\
\hline 1. & Panel Listrik 3 & $\mathrm{R}$ & NYAF 16 & 20,7 \\
& Phase & $\mathrm{S}$ & NYAF 16 & 15,1 \\
& & $\mathrm{~T}$ & NYAF 16 & 14,7 \\
2. & ACPDB & $\mathrm{N}$ & NYAF 16 & - \\
& (Output MCB 3 & $\mathrm{S}$ & NYAF 10 & 11,3 \\
& phase) & $\mathrm{T}$ & NYAF 10 & 13,9 \\
3. & ACPDB & $\mathrm{N}$ & NYAF 10 & - \\
& (Output MCB 1 & $\mathrm{R}$ & NYAF 6 & 1,7 \\
& phase) & $\mathrm{S}$ & NYAF 6 & 2,1 \\
& & $\mathrm{~T}$ & NYAF 6 & 1,8 \\
4. & Output MCB & $(+)$ & NYAF 6 & - \\
& (DC & $(-)$ & NYAF 2,5 & 3,9 \\
& Distribution) & & & \\
\hline
\end{tabular}

Untuk menentukan kelayakan penampang penghantar pembumian atau ukuran minimum yan harus digunakan, dilakukan observasi berkaitan dengan tujuan penelitian.

TABEL 3. HASIL OBSERVASI PENAMPANG PEMBUMIAN

\begin{tabular}{|l|l|l|}
\hline No. & Letak Penghantar Pembumian & $\begin{array}{l}\text { Jenis dan Luas } \\
\text { Penampang }\end{array}$ \\
\hline 1. & Panel Listrik 3 Phase & NYAF $16 \mathrm{~mm}^{2}$ \\
\hline 2. & $\begin{array}{l}\text { Pembumian terhadap ACPDB } \\
\text { (Alternate Current Power } \\
\text { Distribution Box) }\end{array}$ & NYAF $16 \mathrm{~mm}^{2}$ \\
\hline 3. & $\begin{array}{l}\text { Pembumian terhadap IDU } \\
\text { (Indoor Unit) }\end{array}$ & NYAF $16 \mathrm{~mm}^{2}$ \\
\hline 4. & $\begin{array}{l}\text { Pembumian terhadap ODU } \\
\text { (OutdoorUnit) }\end{array}$ & NYAF $16 \mathrm{~mm}^{2}$ \\
\hline
\end{tabular}




\section{Warna Penghantar}

Untuk menentukan kelayakan warna penampang penghantar atau yang harus digunakan, dilakukan observasi berkaitan dengan tujuan penelitian.

\begin{tabular}{|c|c|c|c|}
\hline $\begin{array}{l}\mathbf{N} \\
\mathbf{0}\end{array}$ & Letak Penghantar & $\begin{array}{l}\text { Status } \\
\text { Penghantar }\end{array}$ & $\begin{array}{l}\text { Warna } \\
\text { Penghantar }\end{array}$ \\
\hline \multirow[t]{4}{*}{1.} & Panel Listrik 3 & $\mathrm{R}$ & Merah \\
\hline & Phase & $S$ & Kuning \\
\hline & & $\mathrm{T}$ & Hitam \\
\hline & & $\mathrm{N}$ & Biru \\
\hline \multirow[t]{4}{*}{2.} & ACPDB (Output & $\mathrm{R}$ & Kuning \\
\hline & MCB 3 phase) & S & Kuning \\
\hline & & $\mathrm{T}$ & Hitam \\
\hline & & $\mathrm{N}$ & Biru \\
\hline \multirow[t]{3}{*}{3.} & ACPDB (Output & $\mathrm{R}$ & Merah \\
\hline & MCB 1 phase) & S & Kuning \\
\hline & & $\mathrm{T}$ & Hitam \\
\hline \multirow[t]{2}{*}{4.} & Output MCB (DC & $(+)$ & Merah \\
\hline & Distribution) & $(-)$ & Hitam \\
\hline 5. & $\begin{array}{l}\text { Panel Listrik } 3 \\
\text { Phase }\end{array}$ & $\mathrm{Pe}$ & $\begin{array}{l}\text { Hijau - } \\
\text { kuning }\end{array}$ \\
\hline 6. & ACPDB & $\mathrm{Pe}$ & $\begin{array}{l}\text { Hijau - } \\
\text { kuning }\end{array}$ \\
\hline 7. & $\begin{array}{l}\text { IDU (Indoor } \\
\text { Unit) }\end{array}$ & $\mathrm{Pe}$ & $\begin{array}{l}\text { Hijau - } \\
\text { kuning }\end{array}$ \\
\hline 8. & $\begin{array}{l}\text { ODU (Outdoor } \\
\text { Unit) }\end{array}$ & $\mathrm{Pe}$ & $\begin{array}{l}\text { Hijau - } \\
\text { kuning }\end{array}$ \\
\hline
\end{tabular}

\section{Resistansi Pembumian}

Untuk menentukan tingkat kelayakan resistansi pembumian pada menara transmisi telekomunikasi di site UPD007, maka dilakukan pengukuran berkaitan dengan tujuan penelitian.

TABEL 5. HASIL UKUR RESISTANSI PEMBUMIAN

\begin{tabular}{llll}
\hline No. & $\begin{array}{l}\text { Status } \\
\text { Penghantar }\end{array}$ & $\begin{array}{l}\text { Jarak } \\
\text { Elektroda } \\
\text { Bantu (m) }\end{array}$ & $\begin{array}{l}\text { Hasil } \\
\text { ukur } \\
\text { (Ohm) }\end{array}$ \\
\hline 1. & $\begin{array}{l}\text { Pembumian IDU } \\
\text { (Indoor Unit) }\end{array}$ & $8 \mathrm{~m}$ & 0,68 \\
2. & $\begin{array}{l}\text { Pembumian ODU } \\
\text { (OutdoorUnit) }\end{array}$ & $7 \mathrm{~m}$ & 0,55 \\
3. & $\begin{array}{l}\text { Panel Listrik 3 } \\
\text { Phase }\end{array}$ & $7 \mathrm{~m}$ & 0,55 \\
4. & $\begin{array}{l}\text { Pembumian } \\
\text { ACPDB (Alternate } \\
\text { Current Power } \\
\text { Distribution Box) }\end{array}$ & $8 \mathrm{~m}$ & 0,68 \\
\hline
\end{tabular}

\section{Jenis dan Kapasitas Pengaman}

TABEL 6. HASIL ANALISIS DATA PENGAMAN

\begin{tabular}{|c|c|c|c|c|}
\hline \multirow{2}{*}{ No } & \multirow{2}{*}{$\begin{array}{l}\text { Letak } \\
\text { Pengaman }\end{array}$} & \multicolumn{2}{|c|}{$\begin{array}{c}\text { Jenis dan Kapasitas } \\
\text { Pengaman }\end{array}$} & \multirow{2}{*}{$\begin{array}{l}\text { Layak / } \\
\text { Tidak } \\
\text { Layak }\end{array}$} \\
\hline & & Terpasang & Seharusnya & \\
\hline 1. & $\begin{array}{l}\text { Panel Listrik } \\
3 \text { phase }\end{array}$ & $\begin{array}{l}\text { MCCB } \\
100 \mathrm{~A}\end{array}$ & MCCB 100A & Layak \\
\hline \multirow[t]{2}{*}{2.} & $\begin{array}{l}\text { ACPDB } \\
\text { (Alternate } \\
\text { Current }\end{array}$ & $\begin{array}{l}\text { MCB } 3 \\
\text { Phase 25A } \\
\times 1\end{array}$ & $\begin{array}{l}\text { MCB } 1 \text { Pahse } \\
16 \mathrm{~A} \times 3\end{array}$ & Layak \\
\hline & $\begin{array}{l}\text { Power } \\
\text { Distribution } \\
\text { Box) }\end{array}$ & $\begin{array}{l}\text { MCB } 1 \\
\text { Pahse 63A } \\
\text { x } 3\end{array}$ & $\begin{array}{l}\text { MCB } 1 \text { Pahse } \\
16 \mathrm{~A} \times 3\end{array}$ & Layak \\
\hline 3. & $\begin{array}{l}\text { Input } \\
\text { Rectifier }\end{array}$ & $\begin{array}{l}\text { MCB } 1 \\
\text { Pahse 50A } \\
\times 3\end{array}$ & $\begin{array}{l}\text { MCB } 1 \text { Pahse } \\
16 \mathrm{~A} \times 3\end{array}$ & Layak \\
\hline 4. & $\begin{array}{l}\text { Output } \\
\text { Rectifier (DC } \\
\text { Distribution) }\end{array}$ & $\begin{array}{l}\text { MCB 1 } \\
\text { Phase 32A }\end{array}$ & $\begin{array}{l}\text { MCB } 1 \text { Phase } \\
6 \mathrm{~A}\end{array}$ & Layak \\
\hline
\end{tabular}

Analisis Data:

1) Pada Panel Listrik 3 Phase:

Diketahui:

$$
\begin{aligned}
& \text { Pengaman terpasang }=100 \mathrm{~A} \\
& \text { Tegangan }=380 \mathrm{~V} \\
& \begin{aligned}
\mathrm{S} & =\sqrt{ } 3 \times \mathrm{V} \times \mathrm{I} \\
& =\sqrt{3} \times 380 / 100 \\
& =66.817 \mathrm{VA}
\end{aligned}
\end{aligned}
$$

Berdasarkan hasil tersebut maka dapat diketahui bahwa daya tersambung PLN sebesar 66.000 VA. Dengan demikian diperoleh persamaan:

$$
\begin{aligned}
\mathrm{I} & =\sqrt{3} \times \mathrm{S} / \mathrm{V} \\
& =\sqrt{3} \times 66.000 / 380 \\
& =300,8 \mathrm{~A}
\end{aligned}
$$

Jadi, kapasitas minimum pengaman pada Pada Panel Listrik 3 Phase yang harus digunakan adalah $300,8 / 3=100,27$ A.

2) Pada Panel ACPDB:

a) $\mathrm{MCB} 3$ phase $25 \mathrm{~A}$

Panel ACPDB dalam penelitian ini merupakan panel yang menyuplai seluruh perangkat atau peralatan listrik AC dalam shelter. Untuk menentukan kelayakan dari pengaman yang digunakan berdasarkan arus pengenalnya, maka:

Diketahui:

Tegangan $\quad=220$

Arus R $\quad=11,3$

Arus $\mathrm{S} \quad=13,9$

Arus $\mathrm{T} \quad=7,5$

Untuk daya grup $\mathrm{R}$ :

$$
\mathrm{P} \quad=\mathrm{V} \times \mathrm{I} \times \operatorname{Cos} \varphi
$$

Penyelesaian:

$$
\operatorname{Cos} \varphi=\mathrm{P} / \mathrm{S}
$$

Untuk menentukan nilai $\mathrm{P}$ (Daya Aktif) yang biasanya diperoleh dari spesifikasi sebuah perangkat, mengingat pada penelitian ini tidak dilakukan 
observasi pada perangkat atau peralatan listrik untuk beban $\mathrm{ACPDB}$, maka digunakan rumus:

$$
\begin{array}{rl}
\mathrm{P}=\mathrm{R} & \times \mathrm{I}^{2} \\
\mathrm{R} \quad=\mathrm{V} / \mathrm{I} & \mathrm{R} \quad=220 / 11,3 \\
\mathrm{R} \quad=19,46 \\
\mathrm{P}=19,46 \times 127,69 \\
=2.484,8 \mathrm{Watt} \\
\mathrm{S} \quad \mathrm{V} \times \mathrm{I} \\
=220 \times 11,3 \\
=2.486 \mathrm{VA} \\
\operatorname{Cos} \varphi & =\mathrm{P} / \mathrm{S} \\
\operatorname{Cos} \varphi & =2.484,8 / 2.486 \\
& =0,99 \\
\text { Maka, } & \\
\mathrm{P} & =\mathrm{V} \times \mathrm{I} \times \operatorname{Cos} \varphi \\
& =220 \times 11,3 \times 0,99 \\
& =2.461 \text { Watt }
\end{array}
$$

Untuk daya grup $\mathrm{S}$ :

Penyelesaian:

$$
\mathrm{P} \quad=\mathrm{V} \times \mathrm{I} \times \operatorname{Cos} \varphi
$$

$$
\operatorname{Cos} \varphi=\mathrm{P} / \mathrm{S}
$$

Untuk menentukan nilai P (Daya Aktif) yang biasanya diperoleh dari spesifikasi sebuah perangkat, mengingat pada penelitian ini tidak dilakukan observasi pada perangkat atau peralatan listrik untuk beban ACPDB, maka digunakan rumus:

$$
\begin{array}{rl}
\mathrm{P} & =\mathrm{R} \times \mathrm{I}^{\wedge} 2 \\
\mathrm{R} \quad=\mathrm{V} / \mathrm{I} & \mathrm{R} \quad=220 / 13,9 \\
\mathrm{R} \quad=15,8 \\
\mathrm{P}= & 15,8 \times 193,2 \\
& =3.052,5 \mathrm{Watt} \\
\mathrm{S} & =\mathrm{V} \times \mathrm{I} \\
& =220 \times 13,9 \\
& =3.058 \mathrm{VA}
\end{array}
$$

$\operatorname{Cos} \varphi=\mathrm{P} / \mathrm{S}$

$\begin{aligned} \operatorname{Cos} \varphi & =3.052,5 / 3.058 \\ & =0,99\end{aligned}$

Maka,

$$
=0,99
$$

$$
\begin{aligned}
\mathrm{P} & =\mathrm{V} \times \mathrm{I} \times \operatorname{Cos} \varphi \\
& =220 \times 13,9 \times 0,99 \\
& =3.027,4 \text { Watt }
\end{aligned}
$$

Untuk daya grup $\mathrm{T}$ :

Penyelesaian:

$$
\mathrm{P} \quad=\mathrm{V} \times \mathrm{I} \times \operatorname{Cos} \varphi
$$

$\operatorname{Cos} \varphi=\mathrm{P} / \mathrm{S}$

Untuk menentukan nilai P (Daya Aktif) yang biasanya diperoleh dari spesifikasi sebuah perangkat, mengingat pada penelitian ini tidak dilakukan observasi pada perangkat atau peralatan listrik untuk beban ACPDB, maka digunakan rumus:

$$
\begin{aligned}
& \mathrm{P}=\mathrm{R} \times \mathrm{I}^{2} \\
& \mathrm{R} \quad=\mathrm{V} / \mathrm{I} \\
& \mathrm{R} \quad=220 / 7,5 \\
& \mathrm{R} \quad=29,3 \\
& \mathrm{P}=29,3 \times 56,2 \\
& =1.646 \mathrm{Watt} \\
& \mathrm{S}=\mathrm{V} \times \mathrm{I} \\
& =220 \times 7,5 \\
& =1.650 \mathrm{VA} \\
& \operatorname{Cos} \varphi=\mathrm{P} / \mathrm{S} \\
& \begin{aligned}
\operatorname{Cos} \varphi & =1.646 / 1.650 \\
& =0,99 \\
\text { Maka, } & \\
\mathrm{P} \quad & =\mathrm{V} \times \mathrm{I} \times \operatorname{Cos} \varphi \\
& =220 \times 7,5 \times 0,99 \\
& =1.633,5 \text { Watt }
\end{aligned}
\end{aligned}
$$

Dengan demikian, untuk menentukan kelayakan pada MCB 3 phase yang digunakan terlebih dahulu diketahui daya keseluruhan untuk beban ACPDB adalah sebesar:

$2.461+3.027,4+1.633,5=7.121,9$ Watt

Maka digunakan rumus sebagai berikut:

$$
\begin{aligned}
\mathrm{I} & =\sqrt{3} \times \mathrm{P} / \mathrm{V} \times \operatorname{Cos} \varphi \\
& =\sqrt{3} \times 7.121,9 / 380 \times 0,99 \\
& =32,1 \mathrm{~A}
\end{aligned}
$$

Jadi, kapasitas minimum MCB 3 phase yang harus digunakan adalah $32,1 / 3=10,7 \mathrm{~A}$.

b) MCB 1 Phase $63 \mathrm{~A}$

Untuk mengetahui kelayakan dari MCB yang dimaksud, terlebih dahulu perlu diketahui spesifikasi beban yang digunakan. Spesifikasi beban dalam hal ini unit Rectifier sebagai berikut:

$\begin{array}{ll}\text { Model } & : \text { APR48 } \\ \text { Tegangan Input } & : 220 \mathrm{~V} \\ \text { Arus nominal } & : 12 \mathrm{~A} \\ \text { Daya } & : 1.500 \mathrm{Watt} \\ \text { Tegangan Output } & : 48 \mathrm{VDC} \\ \text { Arus Output } & : 60 \mathrm{~A} \\ \text { Daya Output } & : 1.800 \mathrm{Watt} \\ \text { Frekuensi Output } & : 50 / 60 \mathrm{~Hz}\end{array}$

Dengan demikian, terlebih dahulu ditentukan:

$$
\mathrm{P} \quad=\mathrm{V} \times \mathrm{I} \times \operatorname{Cos} \varphi
$$

Penyelesaian:

$$
\begin{aligned}
\operatorname{Cos} \varphi=\mathrm{P} / \mathrm{S} & \\
\mathrm{S} & =\mathrm{V} \times \mathrm{I} \\
& =220 \times 12 \\
& =2.640 \mathrm{VA}
\end{aligned}
$$

$\operatorname{Cos} \varphi=\mathrm{P} / \mathrm{S}$$$
=1.800 / 2.640
$$$$
=0,68
$$ 
Maka,

$$
\begin{aligned}
\mathrm{P} & =\mathrm{V} \times \mathrm{I} \times \operatorname{Cos} \varphi \\
& =220 \times 12 \times 0,68 \\
& =1.795,2 \mathrm{Watt}
\end{aligned}
$$

Maka dapat diketahui 1 unit Rectifier memiliki daya sebesar 1.795,2 Watt. menentukan kapasitas minimum pengaman yang harus digunakan digunakan perhitungan sebagai berikut:

$$
\begin{aligned}
\mathrm{I} & =\mathrm{P} /(\mathrm{V} \operatorname{Cos} \varphi) \\
& =1.795,2 /(220 \times 0,68) \\
& =12 \mathrm{~A}
\end{aligned}
$$

Jadi, kapasitas minimum pengaman untuk 1 unit Rectifier sebesar $12 \mathrm{~A}$.

3) Pada Input Rectifier:

Untuk mengetahui kelayakan dari MCB yang dimaksud, sama halnya dengan MCB 1 Phase 63A pada ACPDB. Terlebih dahulu perlu diketahui spesifikasi beban yang digunakan. Dengan demikian, terlebih dahulu ditentukan:

Dengan demikian, terlebih dahulu ditentukan:

Penyelesasian:

$$
\mathrm{P} \quad=\mathrm{V} \times \mathrm{I} \times \operatorname{Cos} \varphi
$$

$\operatorname{Cos} \varphi=\mathrm{P} / \mathrm{S}$

$$
\begin{aligned}
\mathrm{S} & =\mathrm{V} \times \mathrm{I} \\
& =220 \times 12 \\
& =2.640 \mathrm{VA}
\end{aligned}
$$

$\operatorname{Cos} \varphi=\mathrm{P} / \mathrm{S}$

$$
\begin{aligned}
& =1.800 / 2.640 \\
& =0,68
\end{aligned}
$$

Maka,

$$
\begin{aligned}
\mathrm{P} & =\mathrm{V} \times \mathrm{I} \times \operatorname{Cos} \varphi \\
& =220 \times 12 \times 0,68 \\
& =1.795,2 \mathrm{Watt}
\end{aligned}
$$

Maka dapat diketahui 1 unit Rectifier memiliki daya sebesar 1.795,2 Watt. Sehingga untuk menentukan kapasitas minimum pengaman yang harus digunakan digunakan perhitungan sebagai berikut:

$$
\begin{aligned}
\mathrm{I} & =\mathrm{P} /(\mathrm{V} \operatorname{Cos} \varphi) \\
& =1.795,2 /(220 \times 0,68) \\
& =12 \mathrm{~A}
\end{aligned}
$$

Jadi, kapasitas minimum pengaman untuk 1 unit Rectifier sebesar 12 A.

\section{4) Pada Output Rectifier (DC Distribution)}

Untuk menentukan kelayakan MCB yang digunakan pada Output Rectifier (DC Distribution) dilakukan pengukuran arus serta

\begin{tabular}{|c|c|c|c|c|c|c|}
\hline No & Letak & Status & $\begin{array}{l}\text { Jenis dan } \\
\text { Luas } \\
\text { Penampang } \\
\end{array}$ & $\begin{array}{l}\text { Hasil } \\
\text { ukur } \\
\text { (A) }\end{array}$ & $\begin{array}{l}\text { KHA } \\
\text { (A) }\end{array}$ & $\begin{array}{l}\text { Layak } \\
/ \\
\text { Tidak } \\
\text { Layak } \\
\end{array}$ \\
\hline \multirow[t]{4}{*}{1.} & $\begin{array}{l}\text { Panel } \\
\text { Listrik } 3\end{array}$ & $\mathrm{R}$ & $\begin{array}{l}\text { NYAF } 16 \\
\mathrm{~mm}^{2}\end{array}$ & 20,7 & 98 & Layak \\
\hline & Phase & $\mathrm{S}$ & $\begin{array}{l}\text { NYAF } 16 \\
\mathrm{~mm}^{2}\end{array}$ & 15,1 & 98 & Layak \\
\hline & & $\mathrm{T}$ & $\begin{array}{l}\text { NYAF } 16 \\
\mathrm{~mm}^{2}\end{array}$ & 14,7 & 98 & Layak \\
\hline & & $\mathrm{N}$ & $\begin{array}{l}\text { NYAF } 16 \\
\mathrm{~mm}^{2}\end{array}$ & - & & Layak \\
\hline \multirow[t]{4}{*}{2.} & $\begin{array}{l}\text { ACPDB } \\
\text { (Output }\end{array}$ & $\mathrm{R}$ & $\begin{array}{l}\text { NYAF } 10 \\
\mathrm{~mm}^{2}\end{array}$ & 11,3 & 73 & Layak \\
\hline & $\begin{array}{l}\text { MCB } 3 \\
\text { phase) }\end{array}$ & S & $\begin{array}{l}\text { NYAF } 10 \\
\mathrm{~mm}^{2}\end{array}$ & 13,9 & 73 & Layak \\
\hline & & $\mathrm{T}$ & $\begin{array}{l}\text { NYAF } 10 \\
\mathrm{~mm}^{2}\end{array}$ & 7,5 & 73 & Layak \\
\hline & & $\mathrm{N}$ & $\begin{array}{l}\text { NYAF } 10 \\
\mathrm{~mm}^{2}\end{array}$ & - & - & Layak \\
\hline \multirow[t]{4}{*}{3.} & $\begin{array}{l}\text { ACPDB } \\
\text { (Output }\end{array}$ & $\mathrm{R}$ & $\begin{array}{l}\text { NYAF } 6 \\
\mathrm{~mm}^{2}\end{array}$ & 1,7 & 54 & Layak \\
\hline & $\begin{array}{l}\text { MCB } 1 \\
\text { phase) }\end{array}$ & S & $\begin{array}{l}\text { NYAF } 6 \\
\mathrm{~mm}^{2}\end{array}$ & 2,1 & 54 & Layak \\
\hline & & $\mathrm{T}$ & $\begin{array}{l}\text { NYAF } 6 \\
\mathrm{~mm}^{2}\end{array}$ & 1,8 & 54 & Layak \\
\hline & & $\mathrm{N}$ & $\begin{array}{l}\text { NYAF } 6 \\
\mathrm{~mm}^{2}\end{array}$ & - & - & Layak \\
\hline \multirow[t]{2}{*}{4.} & $\begin{array}{l}\text { Output } \\
\text { MCB }\end{array}$ & $(+)$ & $\begin{array}{l}\text { NYAF 2,5 } \\
\mathrm{mm}^{2}\end{array}$ & 3,9 & 32 & Layak \\
\hline & $\begin{array}{l}\text { (DC } \\
\text { Distributi } \\
\text { on) }\end{array}$ & $(-)$ & $\begin{array}{l}\text { NYAF 2,5 } \\
\mathrm{mm}^{2}\end{array}$ & & & Layak \\
\hline
\end{tabular}
tegangan yang mengalir pada MCB hingga ke perangkat/beban. Perlu diketahui bahwa beban pada rangkaian ini adalah beban arus searah yang merpakan bagian dari jenis beban resistif yang dimana bersifat resistor murni yang hanya menyerap daya aktif dan tidak menyerap daya reaktif sama sekali.
Diketahui:

$$
\begin{aligned}
& \text { Arus } \\
& \text { Tegangan }=53 \mathrm{VDC} \\
& \mathrm{P} \quad=\mathrm{I} \times \mathrm{V} \\
& \quad=3,9 \times 53 \\
& \quad=206,7 \text { Watt }
\end{aligned}
$$

Berdasarkan hasil tersebut, maka diperoleh:

$$
\begin{aligned}
\mathrm{I} & =\mathrm{P} / \mathrm{V} \\
& =206,7 / 53 \\
& =3,9 \mathrm{~A}
\end{aligned}
$$

Jadi, kapasitas minimum pengaman yang digunakan yaitu 3,9 A.

\section{E. Penghantar}

1. Luas Penampang

TABEL 7. HASIL ANALISIS DATA KELAYAKAN LUAS PENAMPANG

TABEL 8. HASIL ANALISIS DATA KELAYAKAN LUAS PENAMPANG PEMBUMIAN

\begin{tabular}{|l|l|l|l|}
\hline No & $\begin{array}{l}\text { Letak Penghantar } \\
\text { Pembumian }\end{array}$ & $\begin{array}{l}\text { Jenis dan Luas } \\
\text { Penampang }\end{array}$ & $\begin{array}{l}\text { Layak / } \\
\text { Tidak } \\
\text { Layak }\end{array}$ \\
\hline 1. & Panel Listrik 3 Phase & NYAF 16 $\mathrm{mm}^{2}$ & Layak \\
\hline 2. & $\begin{array}{l}\text { Pembumian terhadap } \\
\text { ACPDB (Alternate } \\
\text { Current Power } \\
\text { Distribution Box) }\end{array}$ & NYAF $16 \mathrm{~mm}^{2}$ & Layak \\
\hline 3. & $\begin{array}{l}\text { Pembumian terhadap } \\
\text { IDU (Indoor Unit) }\end{array}$ & NYAF $16 \mathrm{~mm}^{2}$ & Layak \\
\hline 4. & $\begin{array}{l}\text { Pembumian terhadap } \\
\text { ODU (OutdoorUnit) }\end{array}$ & NYAF $16 \mathrm{~mm}^{2}$ & Layak \\
\hline
\end{tabular}


Berdasarkan hasil analisis diatas, seluruh penghantar pembumian yang digunakan disetiap titiknya dikatakan layak berdasarkan minimum luas penampang pembumian yang dijelaskan pada Tabel 8 yang dimana untuk seluruh penampang ini dikategorikan untuk diproteksi secara mekanis dan juga diproteksi terhadap korosi.

2. Warna Penghantar

TABEL 9. HASIL IDENTIFIKASI WARNA

\begin{tabular}{|c|c|c|c|c|c|}
\hline \multicolumn{6}{|c|}{ PENGHANTAR } \\
\hline No & $\begin{array}{l}\text { Letak } \\
\text { Penghantar }\end{array}$ & Status & $\begin{array}{l}\text { Warna } \\
\text { Penghantar }\end{array}$ & $\begin{array}{l}\text { Standar } \\
\text { PUIL 2011 }\end{array}$ & $\begin{array}{l}\text { Sesuai / T } \\
\text { idak Sesuai }\end{array}$ \\
\hline \multirow[t]{6}{*}{1} & \multirow[t]{4}{*}{$\begin{array}{l}\text { Panel Listrik } \\
3 \text { Phase }\end{array}$} & $\mathrm{R}$ & Merah & Hitam & $\begin{array}{l}\text { Tidak } \\
\text { Sesuai }\end{array}$ \\
\hline & & $\mathrm{S}$ & Kuning & Colelat & $\begin{array}{l}\text { Tidak } \\
\text { Sesuai }\end{array}$ \\
\hline & & $\mathrm{T}$ & Hitam & $\begin{array}{l}\mathrm{Abu}- \\
\mathrm{Abu}\end{array}$ & $\begin{array}{l}\text { Tidak } \\
\text { Sesuai }\end{array}$ \\
\hline & & $\mathrm{N}$ & Biru & Biru & Sesuai \\
\hline & \multirow{4}{*}{$\begin{array}{l}\text { ACPDB } \\
\text { (Output } \\
\text { MCB } 3 \\
\text { phase) }\end{array}$} & $\mathrm{R}$ & Merah & Hitam & $\begin{array}{l}\text { Tidak } \\
\text { Sesuai }\end{array}$ \\
\hline & & $\mathrm{S}$ & Kuning & Colelat & $\begin{array}{l}\text { Tidak } \\
\text { Sesuai }\end{array}$ \\
\hline \multirow{2}{*}{2} & & $\mathrm{~T}$ & Hitam & $\begin{array}{l}\mathrm{Abu}- \\
\mathrm{Abu}\end{array}$ & $\begin{array}{l}\text { Tidak } \\
\text { Sesuai }\end{array}$ \\
\hline & & $\mathrm{N}$ & Biru & Biru & Sesuai \\
\hline \multirow[t]{4}{*}{3} & \multirow{4}{*}{$\begin{array}{l}\text { ACPDB } \\
\text { (Output } \\
\text { MCB } 1 \\
\text { phase) }\end{array}$} & $\mathrm{R}$ & Merah & Hitam & $\begin{array}{l}\text { Tidak } \\
\text { Sesuai }\end{array}$ \\
\hline & & $\mathrm{S}$ & Kuning & Colelat & $\begin{array}{l}\text { Tidak } \\
\text { Sesuai }\end{array}$ \\
\hline & & $\mathrm{T}$ & Hitam & $\begin{array}{l}\mathrm{Abu}- \\
\mathrm{Abu}\end{array}$ & $\begin{array}{l}\text { Tidak } \\
\text { Sesuai }\end{array}$ \\
\hline & & $\mathrm{N}$ & Biru & Biru & Sesuai \\
\hline \multirow[t]{2}{*}{4} & $\begin{array}{l}\text { Output } \\
\text { MCB (DC }\end{array}$ & $(+)$ & Merah & $\begin{array}{l}\text { Tidak } \\
\text { ditentukan }\end{array}$ & Sesuai \\
\hline & Distribution) & $(-)$ & Hitam & $\begin{array}{l}\text { Tidak } \\
\text { ditentukan }\end{array}$ & Sesuai \\
\hline 5 & $\begin{array}{l}\text { Panel Listrik } \\
3 \text { Phase }\end{array}$ & $\mathrm{Pe}$ & $\begin{array}{l}\text { Hijau - } \\
\text { kuning }\end{array}$ & $\begin{array}{l}\text { Hijau - } \\
\text { kuning }\end{array}$ & Sesuai \\
\hline 6 & CPDB & $\mathrm{Pe}$ & $\begin{array}{l}\text { Hijau - } \\
\text { kuning }\end{array}$ & $\begin{array}{l}\text { Hijau - } \\
\text { kuning }\end{array}$ & Sesuai \\
\hline 7 & $\begin{array}{l}\text { IDU (Indoor } \\
\text { Unit) }\end{array}$ & $\mathrm{Pe}$ & $\begin{array}{l}\text { Hijau - } \\
\text { kuning }\end{array}$ & $\begin{array}{l}\text { Hijau - } \\
\text { kuning }\end{array}$ & Sesuai \\
\hline 8 & $\begin{array}{l}\text { ODU } \\
\text { (Outdoor } \\
\text { Unit) }\end{array}$ & $\mathrm{Pe}$ & $\begin{array}{l}\text { Hijau - } \\
\text { kuning }\end{array}$ & $\begin{array}{l}\text { Hijau - } \\
\text { kuning }\end{array}$ & Sesuai \\
\hline
\end{tabular}

\section{F. Resistansi Pembumian}

TABEL 10. HASIL ANALISIS DATA RESISTANSI PEMBUMIAN

\begin{tabular}{|c|c|c|c|c|}
\hline \multirow[b]{2}{*}{ No. } & \multirow{2}{*}{$\begin{array}{l}\text { Letak } \\
\text { Penghantar } \\
\text { Pembumian }\end{array}$} & \multirow{2}{*}{$\begin{array}{l}\text { Jarak } \\
\text { Elektroda } \\
\text { Bantu } \\
\text { (m) }\end{array}$} & \multicolumn{2}{|c|}{$\begin{array}{c}\text { Resistansi } \\
\text { Pembumian }\end{array}$} \\
\hline & & & $\begin{array}{l}\text { Hasil } \\
\text { ukur } \\
(\Omega)\end{array}$ & $\begin{array}{l}\text { Standar } \\
\text { PUIL } \\
2011(\Omega)\end{array}$ \\
\hline 1. & $\begin{array}{l}\text { Proteksi IDU } \\
\text { (Indoor Unit) }\end{array}$ & 8 & 0,68 & \\
\hline 2. & $\begin{array}{l}\text { Proteksi ODU } \\
\text { (OutdoorUnit) }\end{array}$ & 7 & 0,55 & \\
\hline 3. & $\begin{array}{l}\text { Proteksi Panel } \\
\text { Listrik } 3 \text { Phase }\end{array}$ & 7 & 0,55 & $\leq 5$ \\
\hline 4. & $\begin{array}{l}\text { Proteksi ACPDB } \\
\text { (Alternate } \\
\text { Current Power } \\
\text { Distribution Box) }\end{array}$ & 8 & 0,68 & \\
\hline
\end{tabular}

Berdasarkan hasil tersebut menunjukkan bahwa resistansi pembumian pada menara transmisis telekomunikasi di site Telkomas UPD007 dengan spesifikasi perangkat antena 0,6 m, jenis $1+023 \mathrm{Ghz}$, di setiap proteksinya sesuai dengan standar yang ditetapkan oleh [5] yakni sebesar $\leq 5 \Omega$. Beberapa faktor yang mempengaruhi hasil ukur tersebut seperti jenis dan keadaan tanah pada site dimana merupakan jenis tanah rawa serta juga tergantung pada ukuran dan susunan elektrode yang digunakan.

\section{SIMPULAN}

Berdasarkan hasil penelitian dan pembahasan, maka diperoleh kesimpulan sebagai berikut:

1. Pengaman yang dipasang di sistem instalasi listrik pada menara transmisi telekomunikasi di site UPD007 Telkomas menggunakan dua jenis pengaman yaitu MCB (Miniature circuit breaker) dan MCCB (Mold Case Circuit Breaker). Dimana pengaman pada panel listrik 3 phase MCCB (Mold Case Circuit Breaker) sebesar 100A dikategorikan layak. Sama halnya dengan pengaman yang terpasang pada panel ACPDB yang menggunakan MCB 3 phase 25A dan MCB 1 phase masing - masing 63A juga dikategorikan layak berdasarkan hasil analisis data. Sedangkan pengaman pada area Input Rectifier dan Output Rectifier (DC Distribution) masing - masing dikatakan layak berdasarkan hasil analisis data karena MCB pada Input Rectifier menunjukkan kapaitas 50A dimana kapasitas minimumnya sebesar 16A, dan MCB pada Output Rectifier (DC Distribution) terpasang sebesar 32A yang kapasitas minimumnya 6A.

2. Penghantar yang dipasang di sistem instalasi listrik pada menara transmisi telekomunikasi di site UPD007 Telkomas, pada panel listrik 3 phase yang sudut fase dan netralnya menggunakan NYAF $16 \mathrm{~mm}^{\wedge} 2$, pada ACPDB (Alternate Current Power Distribution Box) menggunakan NYAF $10 \mathrm{~mm}^{\wedge} 2$ dan NYAF $6 \mathrm{~mm}^{\wedge} 2$ (output MCB 3 phase dan MCB 1 phase), dan pada Output MCB (DC Distribution) menggunakan NYAF $10 \mathrm{~mm}^{\wedge} 2$ seluruhnya dikategorikan layak menurut Persyaratan Umum Instalasi Listrik (PUIL) 2011 berdasarkan analisis pada Kapasitas Hantar Arus (KHA) penghantar, kemudian pada penghantar pembumian disetiap titiknya yakni panel listrik 3 Phase, ACPDB (Alternate Current Power Distribution Box), IDU (Indoor Unit), ODU (OutdoorUnit) juga dikategorikan layak. Sedangkan pada standar penggunaan warna penghantar, setiap penghantar fase pada panel listrik 3 phase hingga panel ACPDB sepenuhnya tidak sesuai dengan standar yang ditetapkan, hanya penghantar netral, pembumian, dan Output pada MCB sirkit DC yang sesuai standar Persyaratan Umum Instalasi Listrik (PUIL) 2011. 
3. Resistansi pembumian yang ada di sistem instalasi listrik pada menara transmisi telekomunikasi di site UPD007 Telkomas sepenuhnya dikatakan layak berdasarkan standar Persyaratan Umum Instalasi Listrik (PUIL) 2011, dimana pada setiap titik proteksi seperti IDU (Indoor Unit), ODU (OutdoorUnit), Panel Listrik 3 Phase, dan ACPDB (Alternate Current Power Distribution Box) dihasilkan nilai resistansi pembumian sebesar $\leq 5 \Omega$.

\section{DAFTAR PUSTAKA}

[1] S. Attamimi and R. Rachman, "Perancangan Jaringan Transmisi Gelombang Mikro Pada Link Site Mranggen 2 Dengan Site Pucang Gading," Jurnal Teknologi Elektro, vol. 5, no. 2, p. 142326, 2014.

[2] I. D. Kristiadi and M. I. Nashiruddin, "Analisis Perencanaan Transmisi Microwave Link antara Semarang-Magelang untuk Radio Access Long Term Evolution (LTE)," Buletin Pos Dan Telekomunikasi, vol. 17, no. 2, pp. 95-110, 2019.

[3] A. Hasyim, "Perencanaan dan analisis kehandalan sistem komunikasi radio microwave tampak pandang pada pita frekuensi 12750-13250 MHz [Planning and analysis of the reliability of line of sight microwave radio communication system on 12750-13250 MHz band]," Buletin Pos dan Telekomunikasi, vol. 14, no. 2, pp. 147-160, 2016.

[4] E. B. Sambani, D. S. Anwar, and A. A. Noorfadilah, "Sistem Informasi Geografis Pemetaan Site Telkomsel Pada Pt Telkominfra Regional Jawa Barat," $E$ Proceedings KNS\&I STIKOM Bali, pp. 191195, 2017.

[5] S. N. Indonesia, "Persyaratan Umum Instalasi Listrik 2011 (PUIL 2011)," Jakarta: BSN, 2011.

[6] N. Darna and E. Herlina, "Memilih Metode Penelitian Yang Tepat: Bagi Penelitian Bidang Ilmu Manajemen," Jurnal Ekonologi Ilmu Manajemen, vol. 5, no. 1, pp. 287-292, 2018.

[7] A. Syofian and H. A. Novendri, "Evaluasi Sistem Kelistrikan Pada Gedung Bertingkat Plaza Andalas Padang," Jurnal Teknik Elektro, vol. 6, no. 1, pp. 44-56, 2017. 